\title{
Allelopathy in Alexandrium spp.: effect on a natural plankton community and on algal monocultures
}

\author{
Giovana O. Fistarol ${ }^{1, *}$, Catherine Legrand ${ }^{1}$, Erik Selander ${ }^{2}$, Christian Hummert $^{3}$, \\ Willem Stolte ${ }^{1}$, Edna Granéli ${ }^{1}$
}

${ }^{1}$ Marine Sciences Division, Department of Biology and Environmental Sciences, University of Kalmar, 39231 Kalmar, Sweden ${ }^{2}$ Tjärnö Marine Biological Laboratory, Gothenburg University, 45296 Strömstad, Sweden ${ }^{3}$ Labor WEJ, Stenzelring 14b, 21107 Hamburg, Germany

\begin{abstract}
We studied allelopathy in the dinoflagellate genus Alexandrium by testing the effect of A. tamarense on a natural plankton community from Hopavågen Bay, Trondheimsfjord, Norway, and the effect of toxic and non-toxic strains of $A$. tamarense and a toxic strain of $A$. minutum on algal monocultures. Also, a possible relation between the allelopathic effect and the production of paralytic shellfish poison (PSP) toxin was investigated. A. tamarense affected the whole phytoplankton community by decreasing the growth rate and changing the community structure (relative abundance of each species, dominant species). A negative effect of $A$. tamarense was also observed on ciliates, but not on bacteria numbers. In the bioassay with algal monocultures, the diatom Thalassiosira weissflogii and the cryptophyte Rhodomonas sp. were exposed to the filtrate of Alexandrium spp. All tested Alexandrium strains negatively affected T. weissflogii and Rhodomonas sp. cultures, independent of whether PSP toxins were produced. The compounds released by Alexandrium caused lysis of natural and cultured algal cells, suggesting that the allelopathic effect may be connected with previously described ichthyotoxic and haemolytic properties of Alexandrium. Furthermore, the observation that several components of the plankton community were affected by compounds released by A. tamarense emphasizes the importance of allelopathy for the ecology of this species.
\end{abstract}

KEY WORDS: Alexandrium - Allelopathy - Natural community · Algal monocultures · Cysts · Paralytic shellfish poison · PSP method · PSP toxins

\section{INTRODUCTION}

The dinoflagellate genus Alexandrium includes the largest number of toxic species (at least 8 species) associated with harmful algal blooms (HABs) (Anderson 1998). The toxic Alexandrium species (e.g. A. tamarense and $A$. minutum) produce a suite of toxins associated with paralytic shellfish poisoning (PSP), an illness that can affect humans, and causes a series of neurological symptoms (Hallegraeff 1995). Alexandrium species also cause environmental problems due to the effect on co-occurring aquatic organisms. Toxic effects of Alexandrium spp. have been observed on heterotrophic dinoflagellates, ciliates, zooplankton and fishes (Mortensen 1985, Ogata \& Kodama 1986, Hansen 1989, Hansen et al. 1992, Lush \& Hallegraeff
1996, Frangópulos et al. 2000, Tillmann \& John 2002). These negative effects of Alexandrium spp. on aquatic organisms are not always related to PSP toxins (Ogata \& Kodama 1986, Lush \& Hallegraeff 1996, Tillmann \& John 2002), but seem to be caused by lytic compounds, and related to the haemolytic activity of this genus (Simonsen et al. 1995).

Besides toxic effects on organisms from higher trophic levels, some Alexandrium species (A. lusitanicum, A. minutum, A. tamarense, A. catenella) have been reported to cause allelopathic effects on other phototrophic phytoplankton species (Blanco \& Campos 1988, Arzul et al. 1999). Allelopathy refers to any process involving secondary metabolites (in this case, called allelochemicals) released by plants, microorganisms, viruses and fungi that affect competing 
organisms (International Allelopathic Society 1996; available at www-ias.uca.es/bylaws.htm\#CONSTI). The release of allelopathic compounds is an intriguing concept, since these substances would interfere with species interactions. Allelochemicals have been suggested to play an important role in plankton succession, competition and bloom formation (Pratt 1966, Keating 1977, Rice 1984 and references therein, Wolfe 2000, Rengefors \& Legrand 2001, Vardi et al. 2002). Although there is evidence that allelochemicals can indeed affect plankton succession (Pratt 1966, Keating 1977, Vardi et al. 2002), allelopathy among phytoplankton has not yet received the attention it deserves.

Since Alexandrium spp. can affect other aquatic organisms, from other phytoplankton to fishes, it is important to understand how chemicals released by Alexandrium affect planktonic interactions such as competition, allelopathy and species succession. To improve the understanding on the mechanisms of allelopathy, future works should include identification and isolation of the causative allelochemicals, which would provide additional insights into the mode of action of such compounds (Seigler 1996, Einhellig 2002). Use of bioassays is the first step in identifying which fraction or which group of compounds is responsible for a certain toxic effect, in this case, allelopathy.

The aims of our study were to investigate (1) whether Alexandrium tamarense had an allelopathic effect on a natural plankton community, (2) the effect of $A$. tamarense allelochemicals on different plankton groups, community biomass and species dominance, (3) the allelopathic effect of Alexandrium on algal monocultures, and (4) whether the allelopathic effect is related to the production of PSP toxins.

Since allelochemicals must be excreted to the environment to characterize an allelopathic interaction (Willis 1985), all allelopathic assays in this study were performed by exposing the plankton community and the algal cultures to cell-free filtrate of the different Alexandrium species.

\section{MATERIALS AND METHODS}

Allelopathic effect of Alexandrium tamarense on a plankton community. A natural plankton community was collected in Hopavågen Bay, at the entrance of the Trondheimsfjord, Norway, in September 2001. The plankton samples were collected from 2 to $6 \mathrm{~m}$ depth using a 31 Niskin bottle. Water temperature and salinity during sampling were $13.6^{\circ} \mathrm{C}$ and $31.8 \mathrm{psu}$, respectively. The samples were filtered through a $150 \mu \mathrm{m}$ mesh-size nylon net to remove the effect of grazing by mesozooplankton.
Alexandrium tamarense KAC 02 (Kalmar Culture Collection, University of Kalmar) was grown in $\mathrm{f} / 2$ medium (Guillard 1975) at $20^{\circ} \mathrm{C}, 32 \mathrm{psu}$, in a light:dark cycle of $16: 8 \mathrm{~h}, 80 \mu \mathrm{mol}$ photons $\mathrm{m}^{-2} \mathrm{~s}^{-1}$, under cool white fluorescent light. To test whether $A$. tamarense filtrate would have different effects on the plankton community if this alga was grown at a different temperature, a subculture of $A$. tamarense was also grown at $14^{\circ} \mathrm{C}$ (approximately the same temperature as in the bay). Both $A$. tamarense cultures (at 20 and $14^{\circ} \mathrm{C}$ ) were used to test its allelopathic effect and the results were compared. The cultures used in the experiment were in exponential growth, and had $113.3 \times 10^{3}$ cells l$^{-1}$ at that time. The cultures were not axenic.

Cell-free filtrates used in the experiments were obtained by gentle filtration (a pressure lower than $-2 \mathrm{kPa}$ was used to create initial vacuum for the filtration) of Alexandrium tamarense cultures through GF/F glass-fibre filters. Freshly prepared filtrate $(150 \mathrm{ml})$ was added to triplicate tissue culture flasks $(750 \mathrm{ml})$ containing $350 \mathrm{ml}$ of the plankton community. This filtrate corresponded to a final concentration of $34 \times 10^{3}$ cells $\mathrm{l}^{-1}$ of $A$. tamarense. Controls (also in triplicate) were made by adding $150 \mathrm{ml}$ of $\mathrm{f} / 2$ medium instead of filtrate. Nitrate and phosphate concentrations in the control medium were adjusted to the same levels as in the $A$. tamarense filtrate $\left(328.2 \mu \mathrm{M} \mathrm{N}-\mathrm{NO}_{3}{ }^{-}\right.$and $20.4 \mu \mathrm{M} \mathrm{P}-\mathrm{PO}_{4}{ }^{3-}$ ) to avoid discrepancies due to different nutrient conditions. A. tamarense filtrate and control medium were added daily to the plankton community over a period of $3 \mathrm{~d}$. Each day, $150 \mathrm{ml}$ was removed from the test bottles, and replaced with either fresh filtrate or control medium. The bottles were incubated at $14^{\circ} \mathrm{C}$.

The allelopathic effect of Alexandrium tamarense on the plankton community was assessed by daily chlorophyll a concentration measurements, and plankton cell enumeration at the beginning and the end of the experiment. To estimate the allelopathic effect of $A$. tamarense on co-occurring plankton species, we only considered the dominant species and those that allowed reliable cell counts. At least 100 cells of each group were counted per sample, except for Ceratium spp., Chaetoceros spp., and the ciliates Mesodinium rubrum, Lohmaniella oviformis, and tintinnids, from which at least 20 cells of each species/group were counted per sample. A total of at least 600 cells were counted per sample. Besides counting the plankton species cell numbers during the experiment with the plankton community, we observed formation of temporary cysts of Scrippsiella trochoidea. Thus, we also counted the number of cysts (100 to 250 cysts were counted per sample). The effect of $A$. tamarense filtrate on the bacterial community was examined by monitoring the bacterial numbers daily. 
Toxicity of Alexandrium tamarense (KAC 02) cells suspension and filtrate was estimated on 1 occasion using Artemia sp. (Vanhaecke et al. 1981) and Heterocapsa triquetra bioassays (Schmidt \& Hansen 2001).

Allelopathic effect of Alexandrium spp. on algal monocultures. The allelopathic effect of 5 non-axenic strains of A. tamarense (KAC 02, CCAP 1119/4, CCAP 1119/1, CCAP 1119/8, CCAP 1119/9) and 1 strain of $A$. minutum (AM89BM) was investigated on monocultures of the diatom Thalassiosira weissflogii (KAC 32) and the cryptophyte Rhodomonas sp. (KAC 30).

All algal cultures were grown in $\mathrm{f} / 2$ medium prepared with $28 \mathrm{psu}$ seawater, at $20^{\circ} \mathrm{C}$, and a light:dark cycle of 12:12 h, $70 \mu \mathrm{mol}$ photons $\mathrm{m}^{-2} \mathrm{~s}^{-1}$, under cool white fluorescent light. Allelopathic experiments were performed under the same conditions. The cultures used in these experiments were in exponential growth when used in the tests (cell numbers ranged between

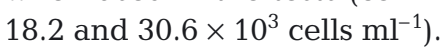

Thalassiosira weissflogii and Rhodomonas sp. were exposed for $48 \mathrm{~h}$ to cell-free filtrate from each Alexandrium strain. The test was made in triplicate $20 \mathrm{ml} \mathrm{scin-}$ tillation glass vials. Alexandrium filtrate and the target species cells were combined to give a final concentration corresponding to $10.5 \times 10^{3}$ Alexandrium: $42 \times 10^{3}$ target cells $\mathrm{ml}^{-1}, 1: 4$ ratio. This was the initial concentration in the test bottles. Controls were made as previously described. The allelopathic effect on the target cells was measured by comparing the cell numbers in the filtrate treatments with the controls after 24 and $48 \mathrm{~h}$. The difference between the cell numbers in the controls (Ctn) and in the filtrate treatments (Ftn) for the same sampling occasion, normalized by the cell numbers in the control, and expressed as percentage (Eq. 1), was called the allelopathic effect (AE). It represents the percentage of decrease or increase of cells in the filtrate relative to the control.

$$
\mathrm{AE}=\left[\frac{(\mathrm{Ctn}-\mathrm{Ftn})}{\mathrm{Ctn}}\right] \times 100
$$

Relation between toxicity and allelopathy. By comparing the effect of the toxic and non-toxic species/ strains of Alexandrium on Thalassiosira weissflogii and Rhodomonas sp., we tested whether the allelopathic effect of Alexandrium spp. was associated with the production of PSP toxins. PSP toxins were analyzed using HPLC, to identify the toxic and non-toxic Alexandrium. Samples for the toxin analysis $(50 \mathrm{ml})$ were taken at the beginning of the experiment with the algal monocultures.

Analytical procedures. Samples for cell counts of Alexandrium spp. and natural plankton species were preserved with acidic Lugol's solution, and counted with an inverted microscope according to Utermöhl (1958). Samples for cell counts of target algae were preserved by freezing with liquid-N (Thalassiosira weissflogii), and with glutaraldehyde $0.5 \%$ (Rhodomonas sp.). Counts of T. weissflogii and Rhodomonas sp. were done using a flow cytometer (FACScalibur, Becton Dickinson). Bacterial abundance was estimated by flow cytometry according to the method of del Giorgio et al. (1996).

Chlorophyll a concentrations were determined by fluorometry using ethanol extracts of cells retained on GF/C filters (Jespersen \& Christoffersen 1987). Specific growth rates of the phytoplankton community were calculated based on the chlorophyll a values, according to Eq. (2):

$$
\mu\left(\mathrm{d}^{-1}\right)=\frac{\left(\ln N_{1}-\ln N_{0}\right)}{t}
$$

where $N_{1}$ and $N_{0}$ are the chlorophyll a concentrations at $t_{1}$ and $t_{0}$, and $t$ is the time, in days, between sampling occasions.

The Artemia sp. bioassay used to test the toxicity of Alexandrium tamarense was based on Vanhaecke et al. (1981). Artemia sp. eggs were hatched in filtered seawater $(31.5 \mathrm{psu})$, at $20^{\circ} \mathrm{C}$ under continuous aeration and light. After $24 \mathrm{~h}$, hatched nauplii were transferred to freshly filtered seawater and kept for an additional $24 \mathrm{~h}$. The test was performed in multiwell plates (Falcon, 12 wells), and approximately 30 Artemia sp. were added per well. The toxic effect of both cell suspension and filtrate of A. tamarense on Artemia sp. was tested. Cells and filtrate were added to each well, corresponding to $34 \times 10^{3}$ cells $\mathrm{l}^{-1}$ of $A$. tamarense. f/2 medium was used as a control. Mortality of Artemia sp. nauplii was examined after $24 \mathrm{~h}$ by counting, with a stereomicroscope, the number of dead nauplii and comparing with the total number (percentage mortality).

A bioassay with the dinoflagellate Heterocapsa triquetra, based on Schmidt \& Hansen (2001), was performed by exposing $H$. triquetra cells to cell suspension and filtrate of Alexandrium tamarense and observing the number of non-motile cells after $4 \mathrm{~h}$. Cell suspension and filtrates of $A$. tamarense $(2 \mathrm{ml}$, final concentration $34 \times 10^{3}$ cells $\mathrm{l}^{-1}$ ) were mixed with $H$. tri-

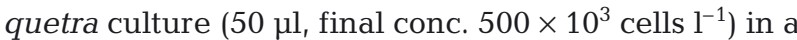
multiwell plate (Falcon, 12 wells). Control experiments were carried out using $\mathrm{f} / 2$ medium instead of the $A$. tamarense culture. All treatments were carried out in triplicate. After $4 \mathrm{~h}$ of incubation, the number of nonmotile $H$. triquetra was counted in each well, then $20 \mu \mathrm{l}$ of Lugol's solution was added to the wells and the total number of $H$. triquetra cells was counted. The results were expressed as percentage of non-motile $H$. triquetra relative to total cell numbers. 


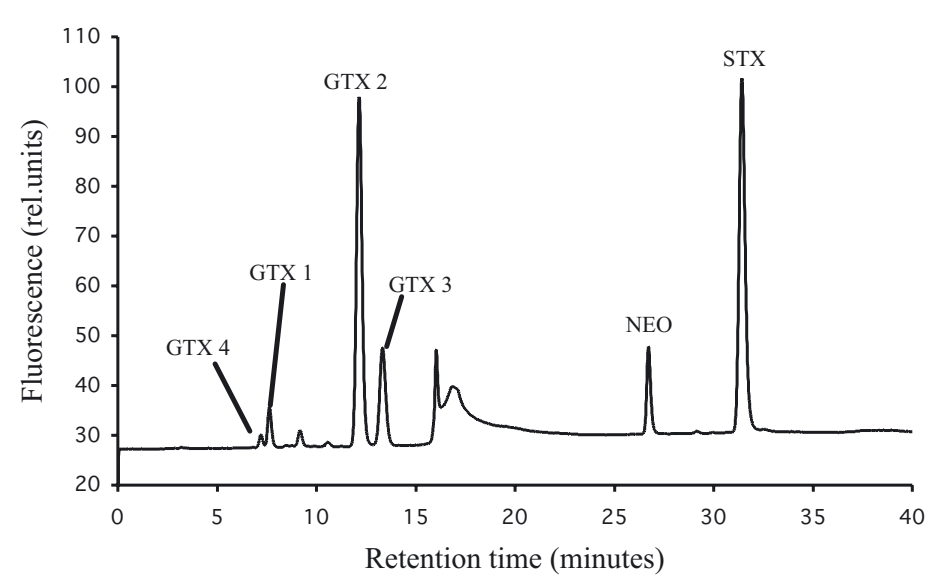

Fig. 1. Chromatogram of paralytic shellfish poison (PSP) standard mixture obtained using method described in 'Materials and methods'. GTX: gonyautoxin; STX: saxitoxin; NEO: neosaxitoxin; rel. units: relative units

PSP toxins analysis. PSP toxins were measured after separation by ion-pair chromatography and fluorometric detection after post-column oxidation. The separation was done using only 1 injection run to analyze gonyautoxins (GTXs 1-4), saxitoxins (STX), and neosaxitoxin (NEO) (Fig. 1). Algal cells were collected on $\mathrm{GF} / \mathrm{F}$ filters and stored at $-20^{\circ} \mathrm{C}$ until analysis. The cells were extracted in $0.03 \mathrm{M}$ acetic acid, in an ice bath by sonication (3 times for $1 \mathrm{~min}$, Ultrasonic Liquid Processor XL, Heat Systems). For determination of Nsulfocarbamoyl toxins, $150 \mu \mathrm{l}$ of the acetic acid extract was mixed with $37 \mu \mathrm{l}$ of $1.0 \mathrm{~N}$ hydrochloric acid and heated for $15 \mathrm{~min}$ at $90^{\circ} \mathrm{C}$. After cooling down to room temperature the mixture was neutralized with $75 \mu \mathrm{l}$ of 1.0 M sodium acetate. Samples were centrifuged for $10 \mathrm{~min}(20800 \mathrm{~g}$, Eppendorf Centrifuge 5417C) and the supernatant was filtered through a $0.45 \mu \mathrm{m}$ PTFE (Scantec Lab, No. F2504-3) filter before injection into the HPLC system. Standards for saxitoxin (STX), neosaxitoxin (NEO), and gonyautoxins (GTX1, 2, 3, and 4) were purchased from the National Research Council, Marine Analytical Chemistry Standards Program (NRC-PSP-1B), Halifax, Nova Scotia, Canada. The standard run contained a mixture of STX (1.453 $\mu \mathrm{M}), \operatorname{NEO}(1.404 \mu \mathrm{M}), \operatorname{GTX} 1(1.118 \mu \mathrm{M}), \operatorname{GTX} 2(0.961$ $\mu \mathrm{M}), \operatorname{GTX} 3(0.233 \mu \mathrm{M})$, and GTX4 (0.490 $\mu \mathrm{M})$ (Fig. 1). All chemicals used were analytical grade. The reversed-phase HPLC system consisted of a MerckHitachi 7000 series equipment, with a fluorescence detector (Merck-Hitachi L7480) and a Phenomenex prodigy ODS(3) $(5 \mu \mathrm{m}) \quad 250-4.6 \mathrm{~mm}$ column. The method used 3 aqueous eluents (Table 1); the gradients are presented in Table 2. The oxidizing reagent used for the post-column derivatization consisted of $10 \mathrm{mM}$ periodic acid and $550 \mathrm{mM} \mathrm{NH}_{3}$ solution (flow: $0.3 \mathrm{ml} \mathrm{min}^{-1}$ ), and the acidifying reagent of $1 \mathrm{M}$ acetic acid (flow: $0.4 \mathrm{ml} \mathrm{min}^{-1}$ ). The post-column reaction took place at $50^{\circ} \mathrm{C}$ using a $10 \mathrm{~m}$ PEAK tubing inner diameter $0.25 \mathrm{~mm}$. Fluorescence detection was employed with excitation and emission wavelengths of 330 and $395 \mathrm{~nm}$ respectively. N-sulfocarbamoyl toxins concentrations were determined by the difference in the concentrations of these readings from those obtained by acetic acid extraction.

Statistical analyses. Statistical analyses were performed using the software SPSS 10 for Macintosh. A Student's $t$-test was used to compare the toxic effect of Alexandrium tamarense grown at 14 and $20^{\circ} \mathrm{C}$ on the plankton community (in terms of growth rate), on the dinoflagellate Scrippsiella trochoidea (number of cells that died and cysts formed), on the dinoflagellate Heterocapsa triquetra (number of non-motile/dead cells), and on the brine shrimp Artemia sp. (mortality). A Student's $t$-test was also used to compare whether growth rates of the phytoplankton community, and the bacterial numbers in the treatment that received $A$.

Table 1. Eluents used in liquid chromatography

\begin{tabular}{|c|c|}
\hline Eluent & Method \\
\hline \multicolumn{2}{|c|}{ Eluent 1} \\
\hline $97.5 \%$ & $\begin{array}{l}11 \mathrm{mM} \text { octanesulfonic acid (sodium salt) } \\
\text { and } 40 \mathrm{mM} \text { phosphoric acid, adjust } \mathrm{pH} \\
\text { to } 6.9 \text { with } \mathrm{NH}_{3}\end{array}$ \\
\hline $2.5 \%$ & Tetrahydrofurane \\
\hline \multicolumn{2}{|c|}{ Eluent 2} \\
\hline $82.5 \%$ & $\begin{array}{l}11 \mathrm{mM} \text { octanesulfonic acid (sodium salt) } \\
\text { and } 40 \mathrm{mM} \text { phosphoric acid, adjust } \mathrm{pH} \\
\text { to } 6.9 \text { with } \mathrm{NH}_{3}\end{array}$ \\
\hline $15 \%$ & Acetonitrile \\
\hline $2.5 \%$ & Tetrahydrofurane \\
\hline \multicolumn{2}{|c|}{ Eluent 3} \\
\hline $97.5 \%$ & $\begin{array}{l}40 \mathrm{mM} \text { phosphoric acid, adjust pH to } 6.9 \\
\text { with } \mathrm{NH}_{3}\end{array}$ \\
\hline $2.5 \%$ & Tetrahydrofurane \\
\hline
\end{tabular}

Table 2. Eluent gradients used for chromatography. Injection: $10 \mu \mathrm{l}$; flow: $1.0 \mathrm{ml} \mathrm{min}^{-1}$; column temperature: room temperature

\begin{tabular}{|lccc|}
\hline Time (min) & Eluent 1 $(\%)$ & Eluent 2 $(\%)$ & Eluent 3 $(\%)$ \\
\hline 0 & 50 & 0 & 50 \\
10 & 50 & 0 & 50 \\
12 & 0 & 100 & 0 \\
35 & 0 & 100 & 0 \\
36 & 100 & 0 & 0 \\
47 & 100 & 0 & 0 \\
48 & 50 & 0 & 50 \\
57 & 50 & 0 & 50 \\
\hline
\end{tabular}


tamarense filtrates, differed from the controls on specific experimental days. ANOVA and Tukey's post hoc test were used to test whether the final plankton community in the control differed from that in the filtrate treatment. A linear regression was used to correlate the allelopathic effect of the different strains of $A$. tamarense and A. minutum on Thalassiosira weissflogii and Rhodomonas sp. with their PSP toxin content. ANOVA was used to test if the regression found was significant. The data were tested for normality and homogeneity of variance. Arcsine of the square root was used to transform the Rhodomonas sp. data to meet these assumptions.

\section{RESULTS}

\section{Effect of Alexandrium tamarense on natural plankton community}

There was no difference between the effect of filtrate obtained from Alexandrium tamarense grown at 14 and $20^{\circ} \mathrm{C}$, for any of the parameters compared, i.e.

Table 3. Plankton species/groups composition in Hopavågen Bay, Trondheim Fjord, Norway. Underlined species/groups are those used to estimate allelopathic effect of Alexandrium tamarense. Initial cell concentration for the dominant species/group is shown $(n=3$, mean $\pm S D)$

\begin{tabular}{|c|c|}
\hline Group/species & Cells $10^{2} \mathrm{l}^{-1}$ \\
\hline \multicolumn{2}{|l|}{ Dinoflagellates } \\
\hline Scrippsiella trochoidea & $95.7 \pm 8.5$ \\
\hline \multicolumn{2}{|l|}{ Ceratium fusus } \\
\hline \multicolumn{2}{|l|}{ Ceratium furca } \\
\hline Ceratium spp. & $0.6 \pm 0.3$ \\
\hline \multicolumn{2}{|l|}{ Gonyaulax spp. } \\
\hline \multicolumn{2}{|l|}{ Dinophysis spp. } \\
\hline Small dinoflagellates $(<30 \mu \mathrm{m})$ & $60 \pm 0,1$ \\
\hline \multicolumn{2}{|l|}{ Flagellates } \\
\hline \multicolumn{2}{|l|}{ Dictyocha speculum } \\
\hline \multicolumn{2}{|l|}{ Diatoms } \\
\hline Leptocylindrus spp. & $341 \pm 34$ \\
\hline Chaetoceros spp. & $2.13 \pm 0.7$ \\
\hline Skeletonema costatum & $35.2 \pm 2.2$ \\
\hline \multicolumn{2}{|l|}{ Eucampia spp. } \\
\hline \multicolumn{2}{|l|}{ Guinardia spp. } \\
\hline \multicolumn{2}{|l|}{ Rhizosolenia spp. } \\
\hline \multicolumn{2}{|l|}{ Pseudo-nitzschia spp. } \\
\hline \multicolumn{2}{|l|}{ Euglenoides } \\
\hline \multicolumn{2}{|l|}{ Ciliates } \\
\hline Mesodinium rubrum. & $7.9 \pm 1.4$ \\
\hline Tintinnids & $5.1 \pm 0.7$ \\
\hline \multicolumn{2}{|l|}{ Tontonia gracillima } \\
\hline \multicolumn{2}{|l|}{ Strobilidium spiralis } \\
\hline Lohmaniella oviformis & $2.8 \pm 0.3$ \\
\hline
\end{tabular}

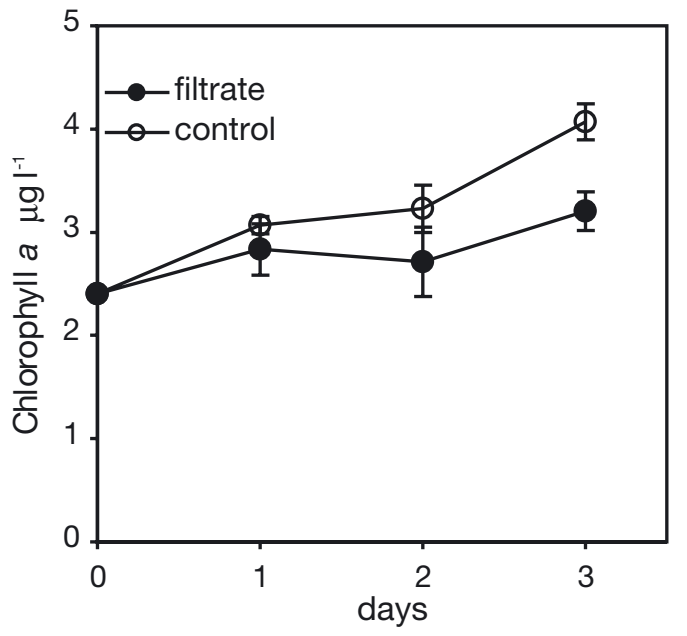

Fig. 2. Growth curve of phytoplankton community (expressed as chlorophyll a) in the treatment with Alexandrium tamarense filtrate and control (filtrate $\mathrm{n}=6$, control $\mathrm{n}=3$, mean $\pm \mathrm{SD}$ )

phytoplankton community growth rates, number of dead Scrippsiella trochoidea cells and temporary cysts formed, bacterial numbers, effect on Heterocapsa triquetra, and on the mortality of Artemia sp. ( $t$-test, p > 0.05 for each comparison). Since there was no difference in the effect of these 2 filtrate treatments, these data were pooled and presented as 1 data set.

The plankton community was composed of different species of dinoflagellates, nanoflagellates, diatoms, euglenoids and ciliates (Table 3). At the start of the experiment, the dominant groups/species were the dinoflagellate Scrippsiella trochoidea, nanoflagellates, and the diatoms Leptocylindrus spp. (Table 3).

The growth of the plankton community was inhibited after exposure to the compounds released by Alexandrium tamarense. After $3 \mathrm{~d}$ exposure, the chlorophyll a concentration was lower in the treatment with A. tamarense filtrate than in the control (Fig. 2). Consequently, the growth rate of the plankton community was significantly lower $(t$-test, $\mathrm{p}<0.05)$ in the filtrate treatment $\left(\mu=0.08 \mathrm{~d}^{-1}\right)$ than in the controls $\left(\mu=0.16 \mathrm{~d}^{-1}\right)$.

Alexandrium tamarense filtrate had an inhibitory effect on ciliates and on all phytoplankton organisms except the small dinoflagellates $(<30 \mu \mathrm{m})$, which increased in the filtrate treatment (Fig. 3). The increase in the cell numbers of small dinoflagellates was not significant at the $5 \%$ level $(t$-test, $p>0.05)$, but only at the $10 \%$ level $(t$-test, $\mathrm{p}<0.1)$. The degree of inhibition was different for each group/species, causing a change in the species abundance and dominance during the experiment. Ciliates, nanoflagellates and the dinoflagellate Scrippsiella trochoidea were the most affected groups/species (Fig. 3). 


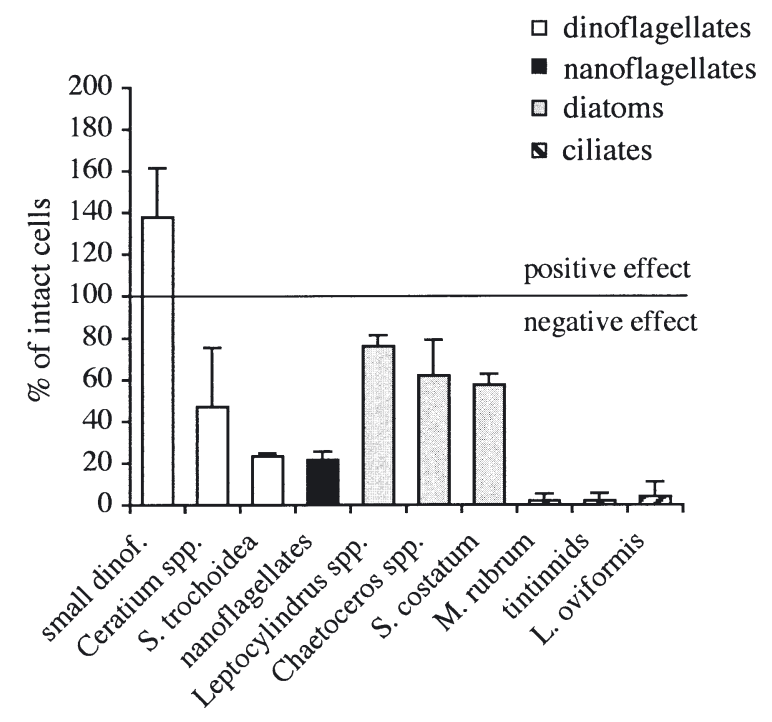

Fig. 3. Percentage of intact cells for each species/group of the plankton community in the treatment with Alexandrium tamarense filtrate relative to cell numbers in the control on Day $3(n=3$, mean $\pm S D)$. Values $>100 \%$ indicate that growth was higher in the filtrate treatment than in the control (positive effect). Full specific names as in Table 3

The relative contribution of each group/species to the total community abundance and the species dominance changed during the experiment in the control and in the filtrate treatment (Fig. 4). However, the changes in the control were different from those in the filtrate treatment, i.e. the resulting plankton community in the filtrate was different from that in the control (ANOVA, $p<0.05$ ), indicating that the additions of filtrate interfered in the algal species interactions and altered the plankton community composition. Thus, the cell numbers of most of the species/groups (Scrippsiella trochoidea, nanoflagellates, Leptocylindrus spp., Skeletonema costatum, and the ciliates Mesodinium rubrum, Lohmaniella oviformis, and tintinnids) in the final plankton community in the filtrate differed significantly from those in the controls (Tukey's post hoc, p < 0.01). The cell numbers of Ceratium spp. in the filtrate differed from the control at $\mathrm{p}<0.075$, and small dinoflagellates at $\mathrm{p}$ $<0.10$. Only Chaetoceros spp. showed no difference between the filtrate and the control at any significance level $(p>0.05)$. The allelopathic effect of Alexandrium tamarense on different organisms of the plankton community enabled species that were less affected by the filtrate, such as Leptocylindrus spp., to achieve dominance over highly affected species, such as nanoflagellates. In the controls on the other hand, nanoflagellates still dominated the community at the end of the experiment, as they had at the beginning.

Microscopical observation revealed that the filtrate of Alexandrium tamarense caused cell blistering, lysis, and loss of pigmentation in all phytoplankton groups/ species, and empty diatom frustules. Besides causing a decrease in the cell number of Scrippsiella trochoidea, the filtrate also induced ecdysis and the formation of temporary cysts in this species. A preliminary test showed that these effects could already be observed after $24 \mathrm{~h}$, although the number of damaged and dead cells and temporary cysts increased with prolonged exposure.

After the first addition of Alexandrium tamarense filtrate, bacterial numbers increased considerably in this treatment. At the end of the experiment, bacteria had a significantly higher biomass $(t$-test, $\mathrm{p}<0.05)$ in the filtrate treatments $\left(9 \times 10^{6}\right.$ bacteria $\left.\mathrm{ml}^{-1}\right)$ than in the control $\left(1.2 \times 10^{6}\right.$ bacteria $\left.\mathrm{ml}^{-1}\right)$ (Fig. 5).

Alexandrium tamarense filtrate had no effect on Artemia sp., while exposure to cell suspensions of $A$. tamarense caused $40 \%$ of mortality in Artemia sp. (Fig. 6A). Both A. tamarense filtrate and cell suspension caused the immobilization and death of the dinoflagellate Heterocapsa triquetra, which were significantly different from those in the control ( $t$-test, $\mathrm{p}<$ 0.01 and $\mathrm{p}<0.05$, respectively) after $4 \mathrm{~h}$ incubation (Fig. 6B). Prolongation of the test $(>10 \mathrm{~h})$, resulted in death (blistering and lysis) of the immobilised cells.
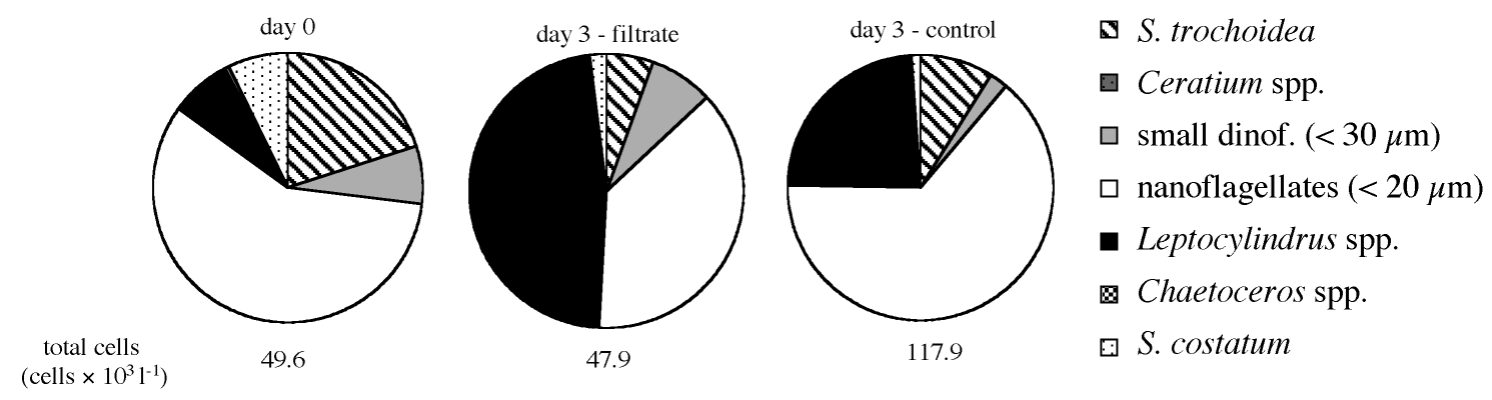

Fig. 4. Relative contribution of different plankton groups/species to total plankton community abundance: initially (Day 0), and after $3 \mathrm{~d}$ in the treatment with Alexandrium tamarense filtrate and in the control. Full specific names as in Table 3 


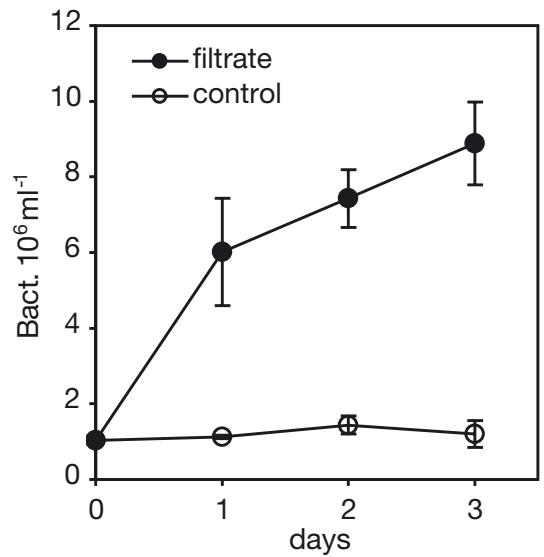

Fig. 5. Growth curve of bacteria in the treatment with Alexandrium tamarense filtrate and in the control (filtrate $\mathrm{n}=6$, control $\mathrm{n}=3$, mean $\pm \mathrm{SD}$ )

\section{Allelopathic experiments with algal cultures}

Alexandrium minutum and 3 strains of $A$. tamarense were toxic, containing PSP toxins with different contents and profiles (Table 4). No PSP toxins were detected for the Strains CCAP 1119/9, and CCAP 1119/1 (A. tamarense).

All Alexandrium strains used in the experiment, independent of whether they produce PSP toxins or not, had an allelopathic effect on Thalassiosira weissflogii and Rhodomonas sp. (Fig. 7). Accordingly, no correlation was found between PSP toxin content and allelopathic effect (ANOVA, p > 0.05 for both species) (Fig. 8). In all filtrate treatments but 1 (A. tamarense CCAP 1119/4), Rhodomonas sp. was more affected than T. weissflogii.

Fig. 6. Effect of Alexandrium tamarense cells and filtrate on Artemia sp. and on Heterocapsa triquetra. (A) Percentage of dead Artemia sp. after $24 \mathrm{~h}$ exposure; (B) percentage of total immobilized (dead and alive) H. triquetra after $4 \mathrm{~h}$ exposure. No mortality of Artemia sp. was observed in control
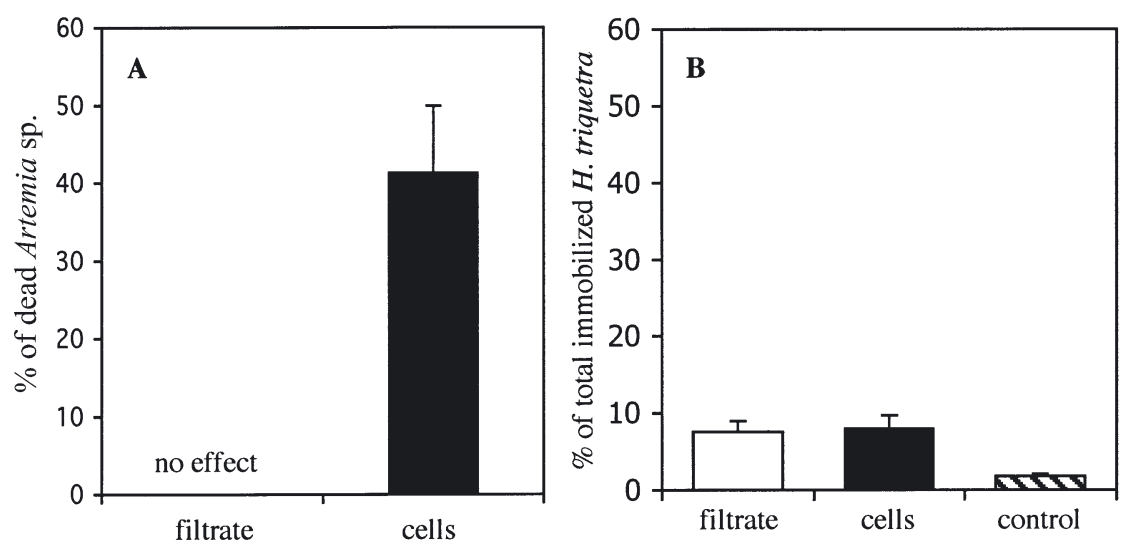

Table 4. Alexandrium spp. Paralytic shellfish poisoning (PSP) toxin profile and cellular toxin content (fmol cell ${ }^{-1}$ ) in $A$. tamarense Strains KAC 02, CCAP 1119/4, CCAP 1119/8, and A. minutum AM89BM. nd = below analytical detection

\begin{tabular}{|lcccccccccccc|}
\hline Strains & STX & NEO & GTX-1 & GTX-2 & GTX-3 & GTX-4 & B1 & C-1 & C-2 & C-3 & C-4 & Total \\
\hline KAC 02 & 8.5 & 3.83 & nd & 0.33 & nd & nd & 0.39 & nd & 0.28 & nd & 0.39 & 13.7 \\
CCAP1119/4 & 0.1 & 1.15 & nd & nd & nd & nd & nd & 0.02 & nd & nd & nd & 1.27 \\
CCAP1119/8 & 0.05 & nd & nd & nd & nd & nd & nd & nd & nd & nd & nd & 0.05 \\
AM89BM & 0.25 & 22.5 & nd & 0.64 & 1.01 & nd & nd & 12.7 & 3.78 & nd & nd & 40.9 \\
\hline
\end{tabular}



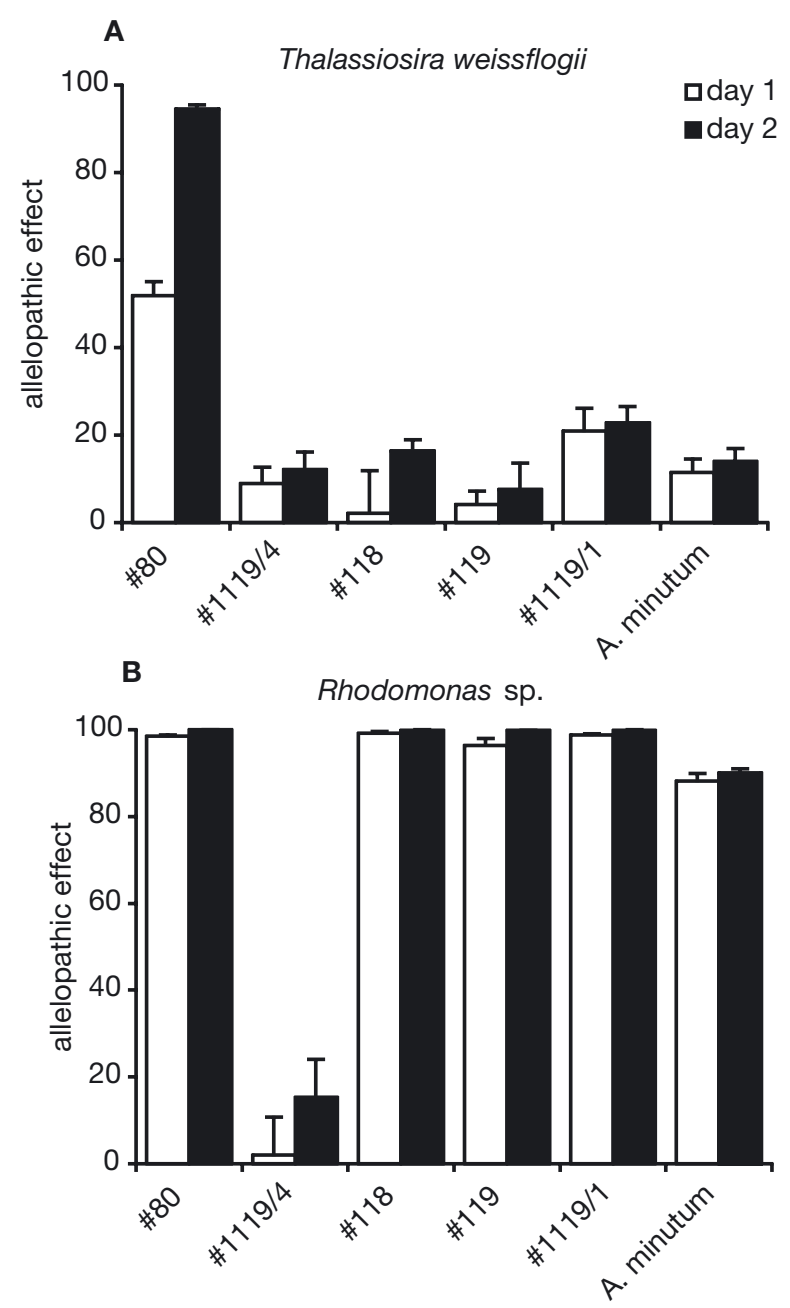

Fig. 7.Alexandrium spp. Allelopathic effect of A. tamarense Strains 80, 1119/4, 118, 119 and 119/1, and A. minutum Strain AM89BM on (A) Thalassiosira weissflogii and (B) Rhodomonas sp. after $24 \mathrm{~h}$ (Day 1) and $48 \mathrm{~h}$ (Day 2) of exposure to cell-free filtrate $(n=3$, mean $\pm \mathrm{SD})$

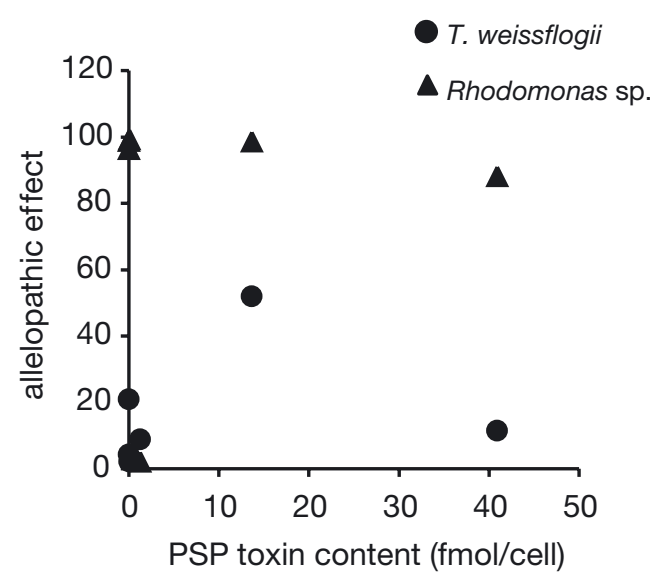

Fig. 8. Alexandrium spp. Relation between allelopathic effect on Thalassiosira weissflogii and Rhodomonas sp. and toxin content of each Alexandrium strain/species showed that filtrate, whether from Alexandrium tamarense grown at 14 or at $20^{\circ} \mathrm{C}$, had the same effects on the natural plankton community. This suggests that, at least within this range, temperature has no effect on the production and/or release of allelochemicals by $A$. tamarense. However, there is need for detailed examination of the effect of temperature on the production and accumulation of allelochemicals.

\section{Effect of Alexandrium spp. on different plankton organisms}

Effect on phytoplankton

The similar results obtained in the experiments with a natural community and algal monocultures (nanoflagellates and Rhodomonas sp. being more affected than diatoms and Thalassiosira weissflogii, respectively) show that the use of laboratory cultures may provide a representative result of the situation in the environment. The higher sensitivity of Rhodomonas sp. to the allelopathic compounds might be due to its weaker cell wall compared (e.g.) to the silica frustules of diatoms. Rhodomonas sp. has also been reported to be sensitive to cyanobacterial allelochemicals (Vance 1965). On the other hand, diatoms were one of the groups most affected by Prymnesium parvum allelochemicals (Fistarol et al. 2003). These reports suggest that the allelopathic effect may be dependent on specific group characteristics of the target algae, and also on the organisms producing the allelochemicals, which may produce compounds with different characteristics.

The effect of Alexandrium tamarense on the phytoplankton from the natural community can be divided into 3 types: (1) strong negative effect, causing a decrease in the biomass of the affected organism (e.g. Scrippsiella trochoidea and nanoflagellates); (2) inhibitory/sublethal effect, whereby the affected organism maintained a positive growth rate, although smaller than that of the control (e.g. Leptocylindrus spp.); (3) positive effect, whereby the target organism had a higher growth than that of the control (e.g. small dinoflagellates). The intensity of the allelopathic effects varied depending on the target organism, as has been observed for other phytoplankton species (Gross et al. 1991, Schmidt \& Hansen 2001, Mulderij et al. 2003). The consequence of the positive growth of some species in our study was that the biomass of the community (chlorophyll a) increased during the experiment, although the increase in chlorophyll $a$ and the growth rate were significantly lower than in the control, demonstrating a general inhibitory effect of $A$. tamarense allelochemicals. In cases where the allelo- 
pathic algae cause very strong negative effects, such as Prymnesium parvum, most phytoplankton organisms die causing a decline in the plankton community, which is unable to maintain a positive growth rate (Fistarol et al. 2003).

It has been proposed that the differential effect of allelochemicals due to differential sensitivity of target species might influence the composition and biomass of phytoplankton communities (Mulderij et al. 2003). Allelochemicals can be beneficial to the releaser species by decreasing the number of competitors. However, because these compounds are released into the water, they may also benefit any species that is not so sensitive to the compounds. Therefore, more resistant species may achieve dominance over species more severely affected, altering the plankton community, as observed in our experiment. This is an example of distributed benefits, whereby certain organisms may indirectly benefit from compounds released by other species, while avoiding the metabolic costs of producing the allelochemicals (Huntley et al. 1986, Lewis 1986).

Although the increase in small dinoflagellate cell numbers was not strongly significant, we cannot say that they were negatively affected. This suggests that this group might have some resistance to allelochemicals released by Alexandrium tamarense, and raises the question if $A$. tamarense can be stimulatory to related organisms. The stimulatory effect may be due to a direct stimulatory effect of the compounds released by A. tamarense, to tolerance mechanisms of related species, or to an indirect effect related to a decrease in competition (phytoplankton) and grazing (ciliates).

\section{Effect on potential predators}

Alexandrium tamarense had a strong negative effect on ciliates, causing the death of most of the cells (98\%). Although some aquatic microorganisms can respond to chemical signals through movement (Wolfe 2000), the ciliates in our experiment could not escape the effect of A. tamarense exudates. However, the strong effect of A. tamarense filtrate on ciliates indicates that these compounds would cause the death of these organisms rather than act as a chemical signal triggering an escape mechanism. Hansen (1989) and Hansen et al. (1992) found that the toxic effect on ciliates becomes evident at high concentrations of A. tamarense (3000 cells ml ${ }^{-1}$ ) and A. ostenfeldii $\left(2000\right.$ cells ml $\left.{ }^{-1}\right)$. The toxic effect on potential predators, especially at high concentrations, can in part explain why blooms of Alexandrium species can develop and persist for months (Hansen 1989).
Cell suspension of Alexandrium tamarense caused mortality of Artemia sp., while A. tamarense cell-free filtrate did, in contrast to the results of Lush \& Hallegraeff (1996), who showed that Alexandrium minutum filtrate can be toxic to Artemia sp. These authors used a filtrate corresponding to approximately $6 \times 10^{5} \mathrm{~A}$. minutum $\mathrm{l}^{-1}$, whereas we used a much lower cell density $\left(3.4 \times 10^{3} A\right.$. tamarense $\left.\mathrm{I}^{-1}\right)$. Although $A$. minutum has a biovolume approximately 3 times less than $A$. tamarense, the cell concentration used by Lush \& Hallegraeff (1996) was 100 times higher than that we used. Probably the higher cell concentration used by Lush \& Hallegraeff (1996) is the reason why the filtrate was toxic in their experiment. It is interesting to note that the filtrate we used (at a concentration of $3.4 \times 10^{3} \mathrm{~A}$. tamarense $\mathrm{l}^{-1}$ ) was already sufficient to have a negative effect on phytoplankton.

\section{Effect on bacteria}

Filtrate from Alexandrium tamarense caused an increase in bacterial numbers in a similar way to allelochemicals released by the ichthyotoxic Prymnesium parvum, although the latter caused a decrease in bacterial production (Fistarol et al. 2003). In the present study, whether the increase in bacteria numbers was a direct stimulatory effect of $A$. tamarense allelochemicals or a response to the increase in organic compounds released by lysing plankton cells is unclear. The increase in bacterial numbers could also be related to the number of nanoflagellates (e.g. mixotrophic and heterotrophic flagellates), which were in high abundance in the control and decreased in the filtrate treatment. Consequently, the grazing pressure on bacteria was lower in the latter bottles, probably contributing to the high bacteria numbers in the filtrate bottles, as has been reported earlier (Shiah \& Ducklow 1994, Carlsson \& Caron 2001).

\section{Consequences of allelopathic effect for the ecology of Alexandrium}

Multiple-purpose compounds

Alexandrium tamarense affected more than 1 level of the plankton community, i.e. potential competitors (phytoplankton) and grazers (ciliates). A. tamarense exudates may, therefore, be used as an allelopathic strategy (competition) and for grazer deterrence. Although mesozooplankton was not present in the natural community, it has been shown that Alexandrium spp. can negatively affect Artemia sp. (Lush \& Hallegraeff 1996, our study), and also other zooplankton 
groups (Bagoien et al. 1996). Many secondary metabolites appear to have multiple functions such as antiherbivory, antiparasitic, antifungal, allelochemical, and internal regulation (Seigler 1996). The release of a substance with multiple purposes gives a further advantage to the producing species and is an efficient strategy (Wolfe 2000). A good example of the advantage of producing multiple-purpose compounds was observed for the prymnesiophyte Chrysochromulina polylepis. During the height of a bloom of C. polylepis in Scandinavian waters (Kattegat/Skagerrak area, 1988), no potential grazers (heterotrophic flagellates, ciliates, copepods) were present in the subsurface bloom, and bacteria concentration and production were extremely low (Nielsen et al. 1990). Maestrini \& Granéli (1991) suggested that a deleterious effect on all components of the food chain most likely contributed significantly to the bloom formation. Later, Schmidt \& Hansen (2001) confirmed the deleterious effect of C. polylepis on several phytoplankton groups (dinoflagellates, diatoms, silicoflagellates, raphidophytes, euglenophytes, cryptophytes, and prasinophytes) in laboratory experiments. Schmidt \& Hansen (2001) also suggested that the release of chemical compounds by C. polylepis could indeed explain a bloom like the one in 1988 , although other factors such as $\mathrm{pH}$ and perhaps $\mathrm{CO}_{2}$ affect the toxicity of C. polylepis, and must be taken into consideration.

\section{Changing plankton community structure}

Allelochemicals have been suggested as influencing planktonic species competition, succession, and bloom formation or maintenance (Pratt 1966, Keating 1977, Rice 1984 and references therein, Lewis 1986, Wolfe 2000, Rengefors \& Legrand 2001, Vardi et al. 2002, Legrand et al. 2003). Regarding competition, since Alexandrium tamarense cells were not present in the test bottles (the allelopathic effect must be caused by released compounds), we do not know if $A$. tamarense would have achieved dominance in the plankton community. However, our results showed that the number of competitors decreased, which would be favourable to allelopathic species. Also, small dinoflagellates were positively affected, indicating that $A$. tamarense would probably beneficiate from the release of allelochemicals.

The changes in the plankton community structure observed in our study support other evidence that allelochemicals can interfere with species interactions and change the plankton community structure. Keating (1977) reported that cell-free filtrates of dominant cyanobacteria from a freshwater lake inhibited the growth of predecessor species, offering evidence for a probable involvement of allelopathy in algal succession in the lake and suggesting the implication of algal allelopathy as a controlling factor in bloom sequence determination. Allelopathy can also be used by algae to achieve dominance, as shown for Olisthodiscus luteus by Pratt (1966) in Narragansett Bay. In the Sea of Galilee, the alternating dominance by the dinoflagellate Peridinium gatunense and the cyanobacterium Microcystis sp. may be caused by mutual densitydependent allelopathic interactions (Vardi et al. 2002).

The primary effect of allelochemicals is on the organisms of the plankton community, causing (e.g.) death and decreasing growth rate. This changes the species dominance and the community structure. Changes in the community structure have indirect effects, because a new community arises, with different dominant species and different competitive requirements (whereby the best competitor will be that most resistant to the allelochemicals). The species interactions in this new community will lead to a new and different species succession than that which would occur without interference by the allelochemicals. Whether directly or indirectly, allelochemicals are the initial trigger factor causing changes and affecting the plankton environment.

\section{Allelochemicals and PSP toxins}

The lack of correlation between PSP toxin production and allelopathic effect shown by our results has also been suggested by other studies. Tillmann \& John (2002) reported no correlation between Alexandrium spp. PSP toxin content and their effect on heterotrophic dinoflagellates. Based on indirect evidence, Arzul et al. (1999) also suggested that substances other than PSP toxins affected phytoplankton. It has also been suggested that it is not the PSP toxins that have toxic effects on zooplankton (Huntley et al. 1986, Lush \& Hallegraeff 1996), fishes (Ogata \& Kodama 1986), and haemolysis (Simonsen et al. 1995, Arzul et al. 1999). All these effects are comparable and similar to those of lytic compounds, as indicated by the microscopic observation of cell lysis of phytoplankton, ciliates (this study), and heterotrophic dinoflagellates (Tillmann \& John 2002). Other ichthyotoxic algae have also been found to have allelopathic properties, such as Prymnesium parvum (Fistarol et al. 2003, Granéli \& Johansson 2003, Skovgaard \& Hansen 2003), Karenia mikimotoi (Gyrodinium cf. aureolum) (Arzul et al. 1993), and Chrysochromulina polylepis (Edvardsen \& Paasche 1998, Schmidt \& Hansen 2001), reinforcing the idea that ichthyotoxicity, allelopathy, and haemolysis may be connected. Arzul et al. (1999) also suggested that allelopathic activity of Alexandrium spp. is caused by a complex of chemicals rather than by a single substance. 
In conclusion, the results presented here showed that compounds produced and released by Alexandrium tamarense are likely to have multiple ecological functions, affecting more than one level of the plankton community and altering the plankton community structure. The fact that our experiment used natural concentrations of $A$. tamarense and the effect was tested on a plankton community in which $A$. tamarense has been reported, indicates that allelopathy is a relevant part of the ecology of this species, interfering in species interactions and, perhaps, in bloom formation.

PSP toxins were not responsible for the allelopathic effect observed. The independence of Alexandrium spp. allelopathy from PSP toxin production shows that this genus produces other active compounds that may be more important to the success of Alexandrium than PSP toxins, since the allelochemicals affect species which directly interact with Alexandrium.

Based on observations of phytoplankton succession in Linsley Pond, Hutchinson (1944) pointed out that some events could not be explained on the basis of abiotic factors and that allelochemicals were the most plausible explanation. We do not want to underrate the significance of abiotic factors on phytoplankton interactions, but to call attention to the fact that allelochemicals also may influence these interactions.

Acknowledgements. We thank the Trondheim Marine System Infrastructure for access to laboratory and field facilities in Hopavågen. We are grateful to K. Rengefors, M. Johansson and F. Norén for helping with sampling at Hopavågen and the excellent team spirit. We also thank K. Rengefors for the final identification of temporary cysts, M. Chauton for providing the culture of Alexandrium tamarense (KAC 02), P. Thor for providing Thalassiosira weissflogii and Rhodomonas sp. cultures, and K. Reinhardt for the technical help with the HPLC analyses. Financial support was provided by the Brazilian National Research Council (CNPq) (PhD grant to G.O.F., process 200384/00-7), by the European Commission through the FATE project (contract EVK3-2001-00055) as part of the ECEUROHAB cluster, and the NUTOX project 'Effect of nutrient ratios on harmful phytoplankton and their toxin production' (MAST3-CT97-0103), and also the program Improving Human Potential - Transnational Access to Research Infrastructure Program of the European Commission, Trondheim Marine RI (grant to C.L., 2001).

\section{LITERATURE CITED}

Anderson DM (1998) Physiology and bloom dynamics of toxic Alexandrium species, with emphasis on life cycle transitions. NATO ASI Ser Ser G 41:29-48

Arzul G, Erard-Le Denn E, Videau C, Jegou AM, Gentien P (1993) Diatom growth repressing factors during an offshore bloom of Gyrodinium cf. aureolum. In: Smayda TJ, Shimizu Y (eds) Toxic phytoplankton blooms in the sea. Elsevier Science, Amsterdam, p 719-724

Arzul G, Seguel M, Guzman L, Erard-Le Denn E (1999) Comparison of allelopathic properties in three toxic
Alexandrium species. J Exp Mar Biol Ecol 232:285-295

Bagoien E, Miranda A, Reguera B, Franco JM (1996) Effects of two paralytic shellfish toxin producing dinoflagellates on pelagic harpacticoid copepod Euterpina acutifrons. Mar Biol 126:361-369

Blanco J, Campos MJ (1988) The effect of water conditioned by a PSP-producing dinoflagellate on the growth of four algal species used as food for the invertebrates. Aquaculture 68:289-298

Cannon JA (1990) Development and dispersal of red tides in the Port River, South Australia. In: Granéli E, Sundström B, Edler L, Anderson DM (eds) Toxic marine phytoplankton. Elsevier Science, New York, p 110-115

Carlsson P, Caron DA (2001) Seasonal variation of phosphorus limitation of bacterial growth in a small lake. Limnol Oceanogr 46:108-120

Chuaychan S (1998) Characteristics of phytoplankton communities in the Trondheimsfjord in 1996. PhD thesis, Norwegian University of Science and Technology, Botanical Institute, Trondheim, Norway

del Giorgio PA, Bird DF, Prairie YT, Planas D (1996) Flow cytometric determination of bacterial abundance in lake plankton with the green nucleic acid stain SYTO 13 Limnol Oceanogr 41:783-789

Edvardsen B, Paasche E (1998) Bloom dynamics and physiology of Prymnesium and Chrysochromulina. NATO ASI Ser Ser G 41:193-208

Einhellig FA (2002) The physiology of allelochemical action: clues and views. In: Reigosa M, Pedrol N (eds) Allelopathy. From molecules to ecosystems. Science Publishers, Enfield, p 1-23

Fistarol GO, Legrand C, Granéli E (2003) Allelopathic effect of Prymnesium parvum on a natural plankton community. Mar Ecol Prog Ser 255:115-125

Frangópulos M, Guisande C, Maneiro I, Riveiro I, Franco J (2000) Short-term and long-term effects of the toxic dinoflagellate Alexandrium minutum on the copepod Acartia clausi. Mar Ecol Prog Ser 203:161-169

Granéli E, Johansson N (2003) Increase in the production of allelopathic substances by Prymnesium parvum cells grown under N- or P-deficient conditions. Harmful Algae $2: 135-145$

Gross EM, Wolk CP, Jüttner F (1991) Fischerellin, a new allelochemical from the freshwater cyanobacterium Fischerella muscicola. J Phycol 27:686-692

Guillard RR (1975) Culture of phytoplankton for feeding marine invertebrates. In: Smith WL, Chanley MH (eds) Culture of marine invertebrate animals. Plenum Press, New York, p 29-60

Hallegraeff GM (1995) Harmful algal blooms: a global overview. In: Hallegraeff GM, Anderson DM, Cembella AD (eds) Manual of harmful marine microalgae. International Oceanographic Commission (IOC) Manual and Guides No. 33. UNESCO, Paris, p 1-22

Hallegraeff GM, Bolch CJ, Blackburn SI, Oshima Y (1991) Species of the toxigenic dinoflagellate genus Alexandrium in southeastern Australian waters. Bot Mar 34:575-587

Hansen PJ (1989) The red tide dinoflagellate Alexandrium tamarense: effect on behaviour and growth of a tintinnid ciliate. Mar Ecol Prog Ser 53:105-116

Hansen PJ, Cembella AD, Moestrup Ø (1992) The marine dinoflagellate Alexandrium ostenfeldii: paralytic shellfish toxin concentration, composition, and toxicity to a tintinnid ciliate. J Phycol 28:597-603

Huntley M, Sykes P, Rohan S, Marin V (1986) Chemicallymediated rejection of dinoflagellate prey by the copepod Calanus pacificus and Paracalanus parvus: mechanism, 
occurrence and significance. Mar Ecol Prog Ser 28: $105-120$

Hutchinson GE (1944) Limnological studies in Connecticut. VI. A critical examination of the supposed relationship between phytoplankton periodicity and chemical changes in lake water. Ecology 25:3-26

Issa AA (1999) Antibiotic production by the cyanobacteria Oscillatoria angustissima and Calothrix parietina. Environ Toxicol Pharmacol 8:33-37

Jespersen AM, Christoffersen K (1987) Measurements of chlorophyll a from phytoplankton using ethanol as extraction solvent. Arch Hydrobiol 109:445-454

Keating KI (1977) Allelopathic influence on blue-green bloom sequence in a eutrophic lake. Science 196:885-886

Legrand C, Rengefors K, Fistarol GO, Granéli E (2003) Allelopathy in phytoplankton - biochemical, ecological and evolutionary aspects. Phycologia (42:406-419)

Lewis WM Jr (1986) Evolutionary interpretation of allelochemical interactions in phytoplankton algae. Am Nat 127:184-194

Lush GJ, Hallegraeff GM (1996) High toxicity of the red tide dinoflagellate Alexandrium minutum to the brine shrimp Artemia salina. In: Yasumoto T, Oshima Y, Fukuyo Y (eds) Harmful and toxic algal blooms. UNESCO, Paris, p 389-392

Maestrini SY, Granéli E (1991) Environmental conditions and ecophysiological mechanisms which led to the 1988 Chrysochromulina polylepis bloom: an hypothesis. Oceanol Acta 14:397-413

Mortensen AM (1985) Massive fish mortalities in the Faroe Island caused by a Gonyaulax excavata red tide. In: Anderson DM, White AW, Baden DG (eds) Toxic dinoflagellates. Elsevier, New York, p 165-170

Mulderij G, Van Donk E, Roelofs GM (2003) Differential sensitivity of green algae to allelopathic substances from Chara. Hydrobiologia 491:261-271

Nielsen TG, Kiørboe T, Bjørnsen PK (1990) Effects of a Chrysochromulina polylepis subsurface bloom on the planktonic community. Mar Ecol Prog Ser 62:21-35

Ogata T, Kodama M (1986) Ichthyotoxicity found in culture media of Protogonyaulax spp. Mar Biol 92:31-34

Pratt DM (1966) Competition between Skeletonema costatum and Olithodiscus luteus in Narragansett Bay and in culture. Limnol Oceanogr 11:447-455

Rengefors K, Legrand C (2001) Toxicity in Peridinium aciculiferum - an adaptative strategy to outcompete other winter phytoplankton? Limnol Oceanogr 46:1990-1997

Rice EL (1984) Allelopathy, 2nd edn. Academic Press, Orlando, p 189-205

Schmidt LE, Hansen PJ (2001) Allelopathy in the prymnesiophyte Chrysochromulina polylepis: effect of cell concentration, growth phase and pH. Mar Ecol Prog Ser 216: $67-81$

Editorial responsibility: Paul Harrison,

Kowloon, Hong Kong
Seigler DS (1996) Chemistry and mechanisms of allelopathic interactions. Agron J 88:876-885

Shiah F, Ducklow HW (1994) Temperature and substrate regulation of bacterial abundance, production and specific growth rate in Chesapeake Bay, USA. Mar Ecol Prog Ser 103:297-308

Shimada H, Hayashi T, Mizushima T (1996) Spatial distribution of Alexandrium tamarense in Funka Bay, southwestern Hokkaido. In: Yasumoto T, Oshima Y, Fukuyo Y (eds) Harmful and toxic algal blooms. UNESCO, Paris, p 219-221

Simonsen S, Møller BL, Larsen J, Ravn H (1995) Haemolytic activity of Alexandrium tamarense cells. In: Lassus $\mathrm{P}$, Arzul G, Erard E, Gentien P, Marcaillou-Le Baut C (eds) Harmful marine algal blooms. Lavoisier, Intercept, Paris, p 513-517

Skovgaard A, Hansen PJ (2003) Food uptake in the harmful alga Prymnesium parvum mediated by excreted toxins. Limnol Oceanog 48:1161-1166

Sorokin YI, Sorokin PY, Ravagnan G (1996) On an extremely dense bloom of the dinoflagellate Alexandrium tamarense in lagoons of the Po River Delta: impact on the environment. J Sea Res 35:251-255

Suikkanen S, Fistarol GO, Granéli E (in press) Allelopathic effect of three Baltic cyanobacteria J Exp Mar Biol Ecol

Therriault JC, Painchaud J, Levasseur M (1985) Controlling the occurrence of Protogonyaulax tamarense and shellfish toxicity in the St. Lawrence Estuary: freshwater runoff and the stability of the water column. In: Anderson DM, White AW, Baden DG (eds) Toxic dinoflagellates. Elsevier, New York, p 141-146

Tillmann U, John U (2002) Toxic effects of Alexandrium spp. on heterotrophic dinoflagellates: an allelochemical defence mechanism independent of PSP-toxin content. Mar Ecol Prog Ser 230:47-58

Utermöhl H (1958) Zur Vervollkommnung der quantitativen Phytoplankton-Methodik. Mitt Int Ver Theor Angew Limnol 9:1-38

Vance BD (1965) Composition and succession of cyanophycean water blooms. J Phycol 1:81-86

Vanhaecke P, Persoone G, Claus C, Sorgeloos P (1981) Proposal for a short-term toxicity test with Artemia nauplii. Ecotoxicol Environ Safety 5:382-387

Vardi A, Schatz D, Beeri K, Motro U, Sukenik A, Levine A, Kaplan A (2002) Dinoflagellate-cyanobacteria communication may determine the composition of phytoplankton assemblage in a mesotrophic lake. Curr Biol 12: $1767-1772$

Willis RJ (1985) The historical basis of the concept of allelopathy. J Hist Biol 18:71-102

Wolfe GV (2000) The chemical defence ecology of marine unicellular plankton: constraints, mechanisms, and impacts. Biol Bull 198:225-244

Submitted: September 30, 2003; Accepted: December 2, 2003 Proofs received from author(s): February 27, 2004 